Human

Development
Psicologia: Teoria e Prática, 21(3), 473-500. São Paulo, SP, set.-dez. 2019. ISSN 1516-3687 (impresso), ISSN 1980-6906 (on-line). doi:10.5935/1980-6906/psicologia. v21n3p473-500. Sistema de avaliação: às cegas por pares (double blind review). Universidade Presbiteriana Mackenzie.

\title{
Communication of students with ASD: A self-regulation of learning based intervention
}

\author{
Andréia T. Leão ${ }^{1}$ \\ (iD) https://orcid.org/0000-0002-1837-7880 \\ Siglia P. H. Camargo ${ }^{1}$ \\ (iD) https://orcid.org/0000-0001-7058-6519 \\ Lourdes Maria B. Frison ${ }^{1}$ \\ iD http://orcid.org/0000-0001-6671-5808
}

To cite this paper: Leão, A. T., Camargo, S. P. H., \& Frison, L. M. B. (2019). Communication of students with ASD: A self-regulation of learning based intervention. Psicologia: Teoria e Prática, 21(3), 473-500. doi:10.5935/1980-6906/psicologia.v21n3p473-500

Submission: 04/04/2019

Acceptance: 17/06/2019

(cc) BY

The content of Psicologia: Teoria e Prática is distributed under the terms of the Creative Commons Attribution License.

1 Federal University of Pelotas (UFPel), Pelotas, RS, Brazil. 


\begin{abstract}
Difficulties in communication/socialization skills represent one of the main barriers to the inclusion of students with autism spectrum disorder (ASD). As a target audience of the special education, students with ASD must attend the common classroom and can receive Specialized Educational Assistance (SEA) support during the after-school activity. This study investigated whether an intervention based on the self-regulation of learning in SEA contributes to the increase in communication of ASD students in this context and the classroom. An experimental multiple baseline design was used across three autistic participants. The results showed an increase in the frequency of non-verbal initiatives and the use of eye contact in response to the communication partners in the SEA. There was no generalization of these gains to the context of the common classroom. Implications and relevance of the results for the inclusion of students with ASD are discussed.
\end{abstract}

Keywords: communication; self-regulation; autism; specialized educational assistance; inclusive education.

\title{
COMUNICAÇÃO DE ESTUDANTES COM TEA: UMA INTERVENÇÃO BASEADA NA AUTORREGULAÇÃO DA APRENDIZAGEM
}

\section{Resumo}

Dificuldades nas habilidades de comunicação/socialização representam uma das principais barreiras para a inclusão de alunos com Transtorno do Espectro Autista (TEA). Enquanto público-alvo da educação especial, alunos com TEA devem frequentar a sala de aula comum, podendo receber o suporte do Atendimento Educacional Especializado (AEE) no contraturno de sua escolarização. Este estudo investigou se uma intervenção ancorada na autorregulação da aprendizagem no contexto do AEE contribui para o incremento da comunicação dos participantes neste mesmo contexto e na sala de aula. Foi utilizado um delineamento experimental de linha de bases múltiplas através de três participantes. Os resultados demonstraram um aumento na frequência de iniciativas não verbais e o uso do contato ocular em respostas aos parceiros de comunicação no AEE. Não houve generalização desses ganhos para o contexto de sala de aula comum. Implicações e relevância dos resultados para a inclusão de alunos com autismo são discutidas.

Palavras-chave: comunicação; autorregulação; autismo; atendimento educacional especializado; educação inclusiva. 


\title{
COMUNICACIÓN DE LOS ALUMNOS CON TEA: INTERVENCIÓN BASADA EN LA AUTORREGULACIÓN DEL APRENDIZAJE
}

\begin{abstract}
Resumen
Dificultades en las habilidades de comunicación/socialización representan una de las principales barreras para la inclusión de alumnos con Trastorno del Espectro Autista (TEA). Como público de la educación especial, los alumnos con TEA deben asistir a la clase común, propensos a recibir apoyo de la Atención Educativa Especializada (AEE) en turno inverso de su escolarización. Este estudio investigó si una intervención anclada en la autorregulación del aprendizaje en el contexto del AEE contribuye al incremento de la comunicación de los participantes en este contexto y clase. Se utilizó un delineamiento experimental de línea de bases múltiples a través de tres participantes. Los resultados demostraron aumento en la frecuencia de iniciativas no verbales y el contacto ocular en respuestas a los compañeros de comunicación en el AEE. Eso no se puede generalizar en el contexto de clase común. Se discute la pertinencia de los resultados para la inclusión de alumnos autistas.

Palabras clave: comunicación; autorregulación; autismo; atención educativa especializada; educación inclusiva.
\end{abstract}

\section{Introduction}

Inclusive education is evidenced by public policies as a possibility of access and participation of students with disabilities in common schools; thus, special education has become a modality, which is transversal in structure, i.e., it passes through the different stages and modalities of teaching through Specialized Educational Assistance ([SEA=AEE], Brasil, 2008). This service must be offered in the after-school activity period, seeking to complement or supplement students' education and aiming for their active participation and autonomy in daily school life (Ropoli, Mantoan, Santos, \& Machado, 2010). The focus of SEA is the development of students' abilities and potentialities, as well as prioritizing the working partnership with the teachers of the common classroom for the development of inclusive actions in the school routine.

The students with autism spectrum disorder (ASD) are among the target audience of SEA. ASD is considered a neurodevelopmental disorder in which the child presents a dyad of impairment in communication, socialization, and behavior (American Psychiatric Association, 2014). The child may persistently show dimin- 
ished levels in the ability to interact and establish a reciprocal communication with the interlocutor, demonstrate repetitive behavior and restricted interest. These characteristics may vary in intensity and severity regarding communication and/or behavior, even among children with the same level of diagnosis. The American Psychiatric Association (2014) classifies the disorder at different levels according to support needs, as follows: level 1, requiring support; level 2, requiring substantial support; level 3, requiring very substantial support.

While children with typical development use gestures, vocalizations, smiles and other symbolic representations to communicate from birth, and broaden and improve the use of these communication techniques for new contexts (Tomasello, 2003), children with ASD have difficulties in expressing desires, do not babble, and make little or no eye contact (Cunha, 2009; Porciúncula, 2016). These difficulties in precursor abilities of language development have repercussions on the restricted interaction/communication of the ASD child and hinder participation in social contexts that involve an alternation in roles, consequently impairing school inclusion.

Communication can be defined as the actions or emissions that the individual produces to achieve a specific goal, either as a way of making a statement or asking for assistance and attention (Bosa, 2002). There will be exchanges of looks, alternation of roles, and sharing of interests and experiences. Some ASD children acquire verbal language and then regress; others develop differently than expected for the age or do not acquire speech (Zanon, Backes, \& Bosa, 2013). Cunha (2009) explained that individuals with ASD who speak tend to have impairment in the capacity to initiate a dialogue or to maintain a reciprocal relationship with alternating roles, with the possible presence of echolalic speech.

Studies on neuropsychology (e.g., Bosa, 2001; Happé \& Frith, 1996) have highlighted the importance of interventions for the development of competencies impaired by ASD, focusing beyond the impairment of the cognitive and social processes of individuals with ASD (Czermainski, 2012). Thus, the development of executive functions involving the use of cognitive processes (flexibility, work memory, selective attention) is highlighted so that in social environments the individual is able to behave in ways that reflect personal objectives. In this way, it is crucial to provide interactive situations that stimulate the development of the capabilities and abilities of ASD children, involving the use of perception and interpretation, favoring the education of symbolic thought and, consequently, of language and communication. 
It is noteworthy that students with ASD tend to present executive dysfunctions related to the inhibition of responses, planning, and cognitive flexibility (Czermainski et al., 2014). Several factors may influence the development of these functions; among them, the stimulus from social environments (Bosa, 2001; Czermainski, Bosa, \& Salles, 2013). Considering the dysfunctions of individuals with ASD concerning communication, it is essential to emphasize that intentional action is the driving force that links language development to executive functions (Czermainski et al., 2013). This means that the mobilization of intentional behaviors is a link that promotes the development of the language and abilities of the executive functions, enabling the individual to understand the role of communication.

Dias and Seabra (2013) pointed out the importance of interventions that stimulate development related to executive function. According to the authors, gains were found regarding autonomy, organization, interaction, and behavior change in typical children. These authors evidenced that the concept of executive functions and self-regulation of learning (SRL) are complementary, although originating from different theoretical approaches. The executive functions are referenced in the field of neuropsychology and self-regulation in sociocognitive theory.

As the pioneer of self-regulation learning theory, Zimmerman (2013) defines SRL as an intentional process in which the learner performs tasks to achieve goals, transforming mental abilities into competencies. The individual becomes an agent of the personal learning process through the mobilization of cognitive processes in the execution of tasks and going through the phases of 1. anticipation/ planning; 2. Execution; and 3. evaluation, which together form a cyclical self-regulatory model. In the phase of anticipation, the student is challenged to define strategic planning, dealing with the procedure related to the execution of a task to achieve goals. This involves managing beliefs, interests, and expectation of results, to plan actions. In the execution phase, the student performs the task by implementing the plan created in the previous phase. In parallel, there is self-control and self-observation of performance. In the self-reflection phase, the student reflects on the learning path chosen and evaluates the effectiveness of their strategic planning. If the objectives were not achieved, the student could plan new actions, thus activating the self-regulating cycle.

In the self-regulation process the student becomes an intentional agent that mobilizes behaviors to achieve goals (Zimmerman, 2013). Proposals based on 
the process of SRL in the SEA could offer favorable possibilities to the communication development of ASD students, minimizing barriers in the context of inclusion. Even though deficits in communication and behavior are considered permanent in the lives of individuals with ASD, advancement usually occurs according to the stimuli and care received (Bosa, 2006). An intervention with emphasis on the phases of the self-regulatory process in SEA shows an organization and a logical structure of thought that can challenge students with ASD to make choices, decisions, and register personal learning process. Due to difficulties in communication, students in the SEA are encouraged to organize and articulate ideas, wishes, and thoughts during moments that involve planning, action, and reflection. This is to facilitate the understanding of the social function of communication in daily school life. In addition to these factors and the growing need to seek evidence-based practices to favor the inclusion of students with ASD, it is important to note that the Brazilian and international academic production in this topic is still scarce. The few published studies found did not address interventions based on the self-regulation process of learning for ASD students, which requires more specific studies on this topic, including research on the usefulness of self-regulation in the development of communication skills, which promotes a more inclusive context for individuals with ASD. Therefore, the objective of this study was to investigate whether an intervention based on the process of SRL contributes to increased communication (frequency and quality of communicative acts) of ASD students in the context of the SEA teacher and common classroom teacher.

\section{Method}

This study represents single case research. Through an experimental design of multiple baselines across three participants (Nunes \& Walter, 2014), we sought to identify the existence of a functional relationship between the independent (intervention based on SRL) and dependent (frequency and quality of the communicative acts of the students) variables in the baseline (phase A) and intervention (phase B) phases. The intervention in SEA was introduced successively for each participant according to the stability (variance less than $50 \%$ in the last two sessions) and tendency (increasing or decreasing) of the data in the baseline (Alberto \& Troutman, 2009), having as a parameter, the variable verbal and non-verbal initiatives of the participants. The baseline sampling was initiated with the three participants simul- 
taneously in both contexts (SEA and Classroom). The involvement of three participants in the research considered the methodological quality criteria in single -case research to establish evidence-based practices (Horner et al., 2005), which requires at least three demonstrations of changes at three different moments.

\subsection{Participants}

The inclusion criteria to participate in this study were: students with medical diagnose of ASD (according to DSM- 5 criteria), being included in elementary school and attending SEA at Danilo Rolin de Moura Autistic Care Center in the after-school activity time. The students should not receive treatment from a speech therapist or receive another intervention to promote communication skills. According to these criteria, professionals from the Autism Center selected three students, ages 10-12 years old, who presented speech skills but had difficulties in communicating.

Participant 1 (male) was in the third year of elementary school and usually communicated using few words to express wishes. The student is rarely communicative and does not recount stories or events about school. The student does not approach other children nor shows the initiative to communicate. Usually, there is a delay before the student accepts the approach of others. The student expresses delight to compliments, usually through jumping or by the clapping the hands. Echolalic speech is presented with the repetition of questions and greetings directed at the student. The teacher noted a lack of communication and independence of the student as barriers, which hindered participation in classes.

Participant 2 (male) was in the fourth grade of elementary school and was considered by parents and teachers to be quiet, caring, and gentle. The student can communicate emotions and desires through the pronunciation of words and phrases to articulate ideas, but he presents difficulties to initiate and/or sustain a conversation. He uses a few nonverbal expressions to communicate. The student is able to focus, stand up when necessary, and perform activities with autonomy. However, the teacher notes that the student is friendless and, during group activities, the student will participate when called upon and only responds to questions directed specifically toward the said student.

Participant 3 (female) was in the fifth year of elementary school, and she was considered timid. The mother reports that she needs to ask to understand her daughter's real needs. She presents her ideas enunciating words and phrases with 
few gestures to communicate and maintain social interaction. The student rejects the approach of strangers. At school, when encountered with doubts or difficulties, the student does not usually ask questions and does not communicate wishes; however, the student has contact with friends. The student accepts the approach of other children, but does not talk or react when someone handles a toy, even when the student is interested in the object.

\subsection{Instruments}

Semi-structured interview with parents and teachers: The interview script included questions to parents and teachers to characterize the participants and to collect information about student's difficulties and preferences to elaborate on the intervention.

Protocol of observation of the frequency and quality of communicative acts: This instrument was designed specifically for this study to capture the frequency of communicative acts, defined as those that have the purpose of communicating through verbal or non-verbal language, either through one's own initiative or by the response to the stimuli of colleagues and the teacher conducting the class. The quality of the communicative acts was defined and measured by the frequency of acts that were emitted, the presence of eye contact and the facial expression during communication, as well as an approach to the interlocutor and touch.

Social validity questionnaire: A questionnaire was designed for this study to investigate the effectiveness, viability, and usefulness of the intervention to aid in the communication of ASD students from the perspective of the SEA teacher. The teacher should mark one of the alternatives in a Likert scale that varied from partially agree to partially disagree about affirmatives related to the aspects listed above.

Intervention fidelity protocol: This protocol was designed to verify that the intervention was conducted as planned in this study and that the results presented can be attributed to the intervention. Therefore, this instrument checked whether the teacher went through the three steps of the intervention: initial problematization, to enable students to think and define objectives; task organization: to give the opportunity for students to ask for help and clear their doubts; and final problematization: to allow students to express their opinion regarding the tasks. 


\subsection{Procedures}

The project was submitted and approved by a research ethics committee through the Brazil Platform ("Plataforma Brasil"). Participants were identified through the Autistic Care Center according to previously established criteria. A semi-structured interview with the parents and teachers of the participants was held to identify their characteristics and preferences in order to elaborate a customized intervention for each of them.

The intervention was performed in the SEA and conducted by the teacher of this attendance, who received guidance and feedback from the researcher before and after each session. The intervention consisted of challenging students to set goals and mobilize behaviors, crossing the cyclical phases of the SRL model with the planning, execution, and evaluation of tasks and the learning path. Every two sessions, the participants summarized and organized the tasks through the construction of a portfolio that allowed students to assess and adjust the approach taken so that objectives can be met. Examples of three performed sessions are attached.

Data collection was performed once a week, for approximately five months, through 20-minute filming in the SEA and 10 minutes in the common classroom during group activities with roommates. Filming was analyzed to fill out a specific protocol regarding the frequency and quality of communicative acts of the students in the respective phases of the study. The percentage of agreement between observers (two independent researchers) was calculated in $20 \%$ of the sessions by the number of concordances divided by the total (agreement + disagreement), multiplied by 100 . For each participant, the average of the percentages of concordances obtained on the frequency of communicative acts in the SEA was calculated at $98 \%$ for participant 1, $90 \%$ for participant 2, and $88 \%$ for participant 3, considering a minimum requirement of $80 \%$ (Horner et al., 2005). Regarding the common classroom, the percentages of agreement obtained were $100 \%$ for participants 1 and 2 and $94 \%$ for participant 3.

At baseline, the teacher performed activities as usual and without receiving guidelines under the principles of self-regulation, while in the intervention, the tasks performed were based on SRL. To implement the intervention, the teacher provided the intended activities according to objectives previously established in the SEA plan to the researcher. The researcher organized the proposals based on 
the principles of SRL, Guiding the SEA teacher on the accomplishment of the tasks during the intervention. The fidelity of the intervention was measured in $100 \%$ of the sessions. On average, there was $85 \%$ fidelity of intervention for participant 1 , $74 \%$ for participant 2 , and $84 \%$ for participant 3. Percentages below a minimum adequacy parameter of $80 \%$ (Horner et al., 2005) were corrected using continuous feedback provided to the SEA teacher.

The data on the frequency of communicative acts were graphically illustrated, allowing the visualization of the impact of the intervention on the dependent variable for each participant. The visual analysis considered the variability, average, and trend of the data that were represented in the two phases of the study. To quantify the size of the effect on the studied variables, the Tau-U (Parker \& Vannest, 2012) was calculated through online software available at www.singlecaseresearch.org, analyzing the statistical significance in the differences found $(p \leq 0.05)$ and respective confidence intervals. As a general measure of the study, the omnibus effect size was calculated, which considers the data of the three participants involved in the survey.

The quality of the communicative acts was analyzed from the average of communicative acts that were issued by the participants within the context. These acts included eye contact, facial expression, touch, and approaching to the communication partner. At the end of the study, a questionnaire was applied to the SEA teacher to verify the social validity of the intervention.

\section{Results}

The results of the contributions of an intervention based on the SRL in the frequency of the communicative acts of the participants are graphically illustrated in both the SEA and classroom contexts. The data regarding verbal and non-verbal language by initiative or response, as well as the results regarding the quality of these acts and their respective effect sizes, are presented in the context of the SEA and subsequently in the classroom for each participant. Figure 3.1 shows the frequency of verbal and non-verbal communicative acts initiated or answered by participants in both contexts. 


\section{SEA}

\section{Non-verbal language}

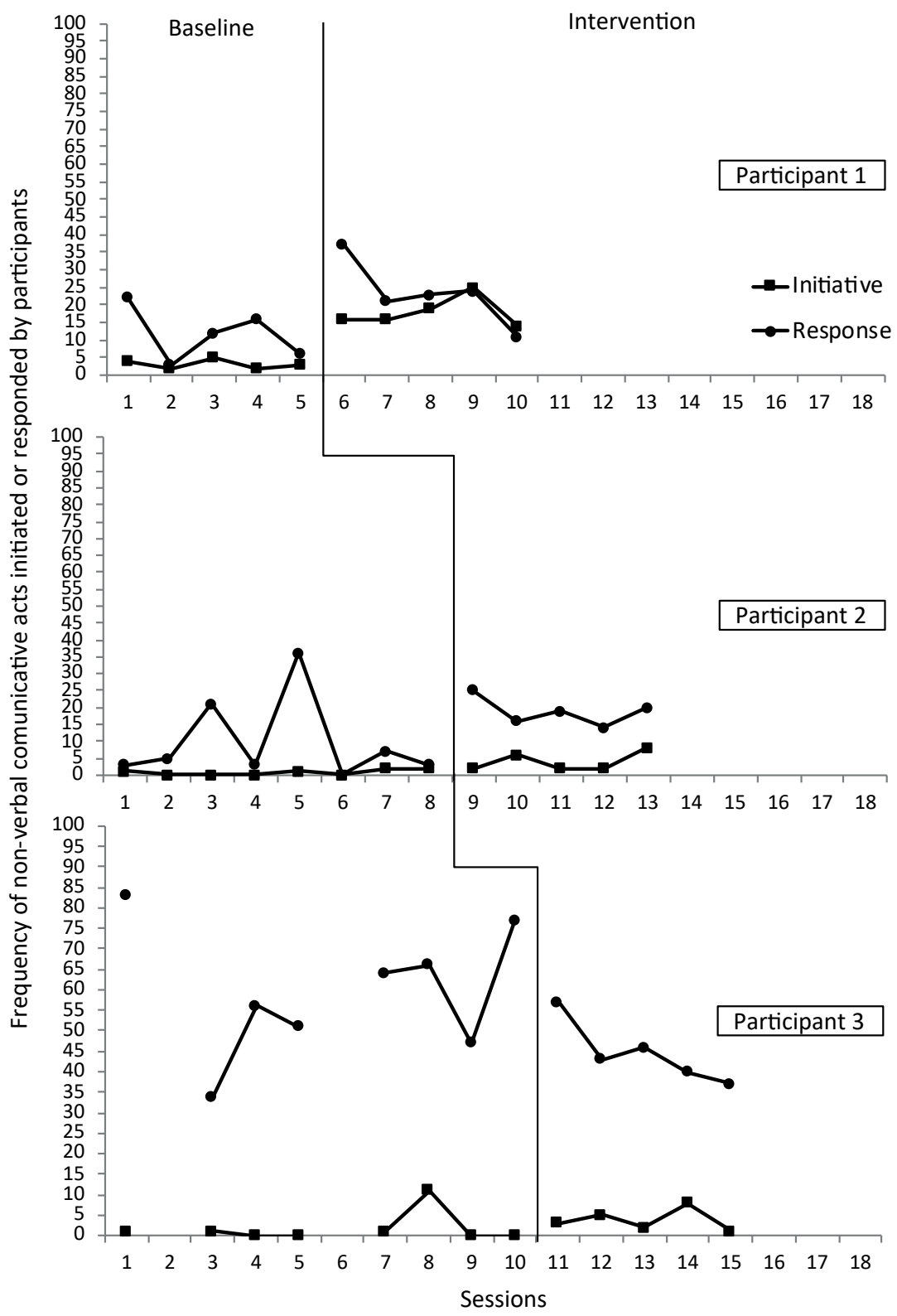


Verbal language

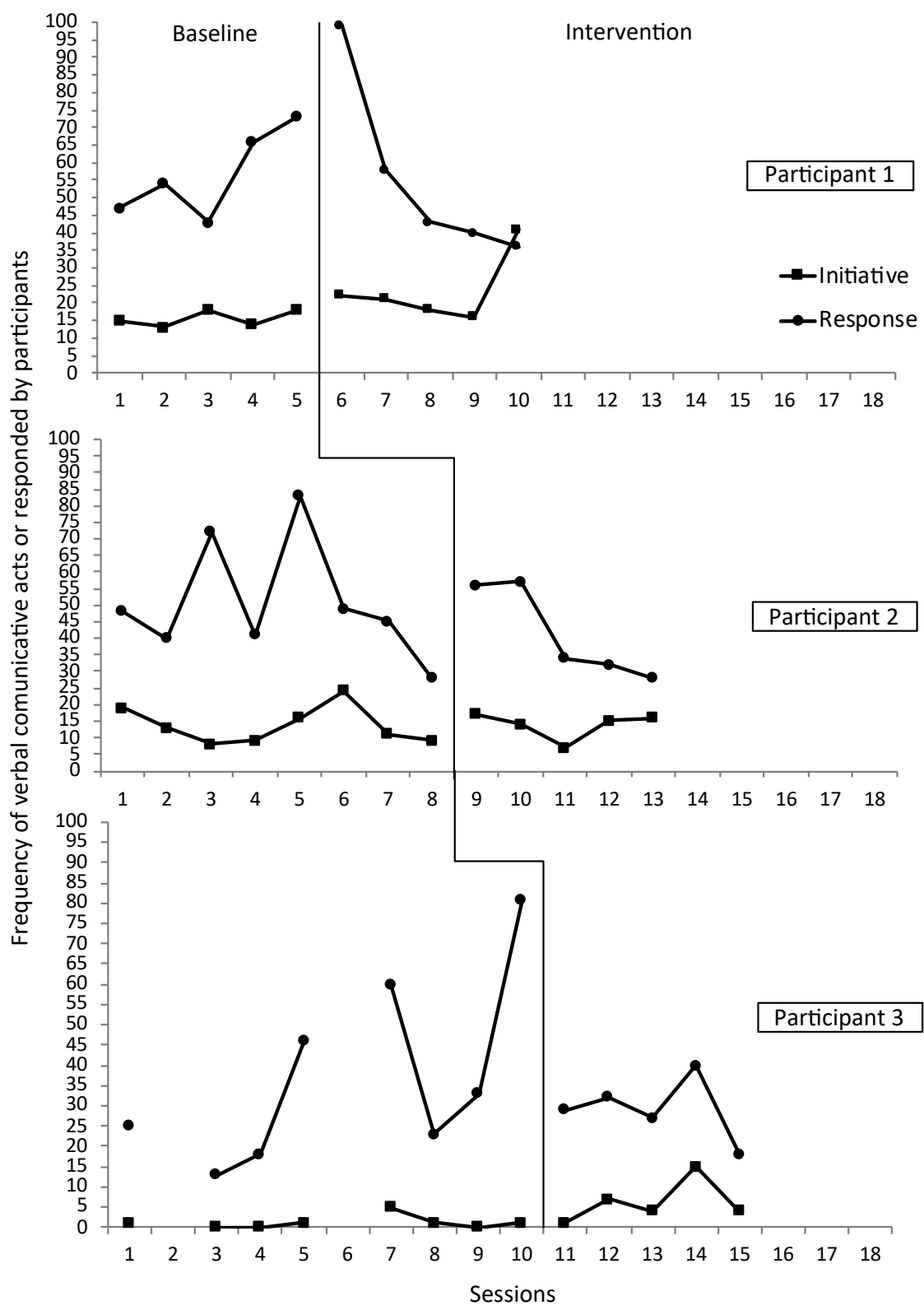




\section{CLASSROOM}

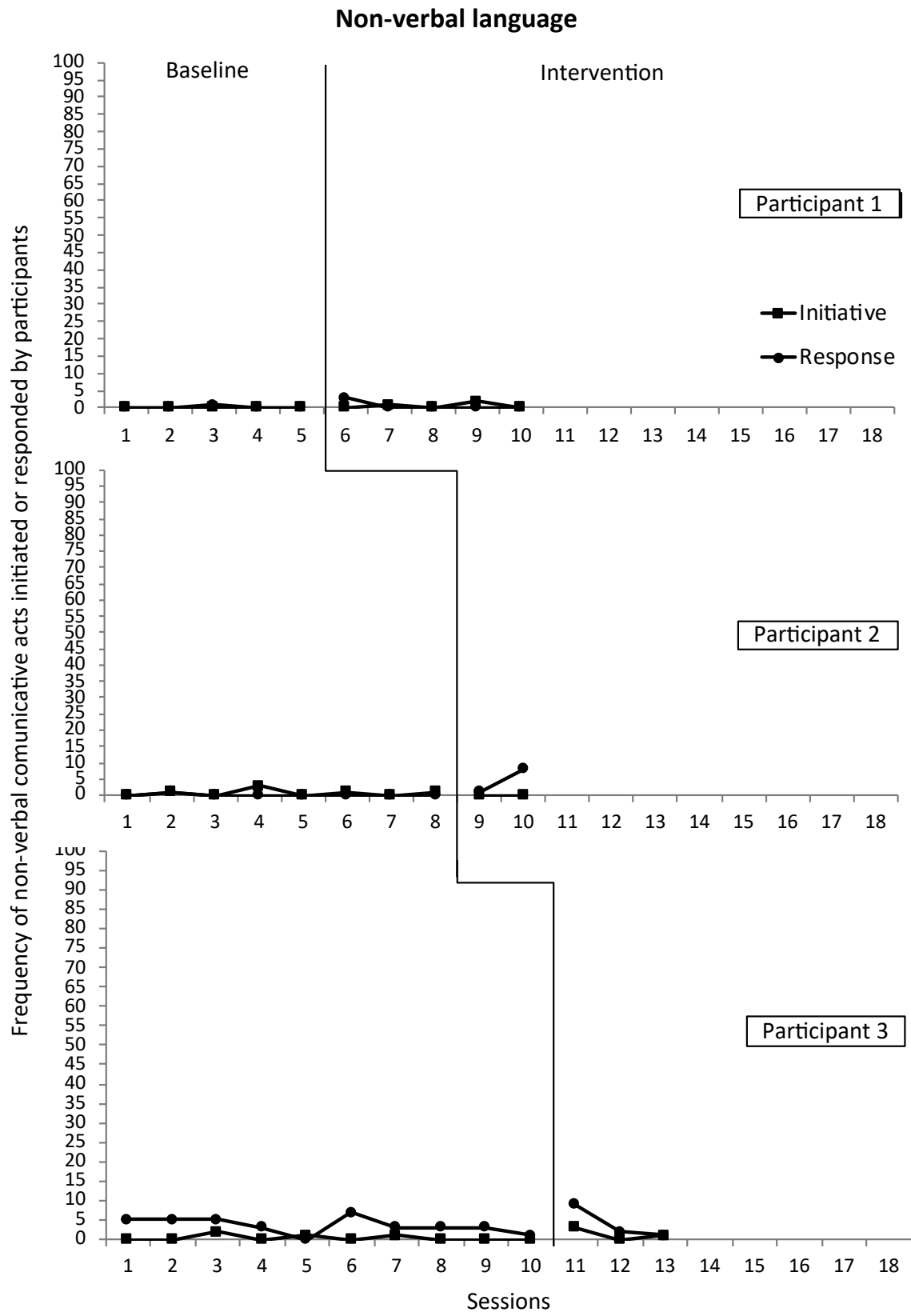




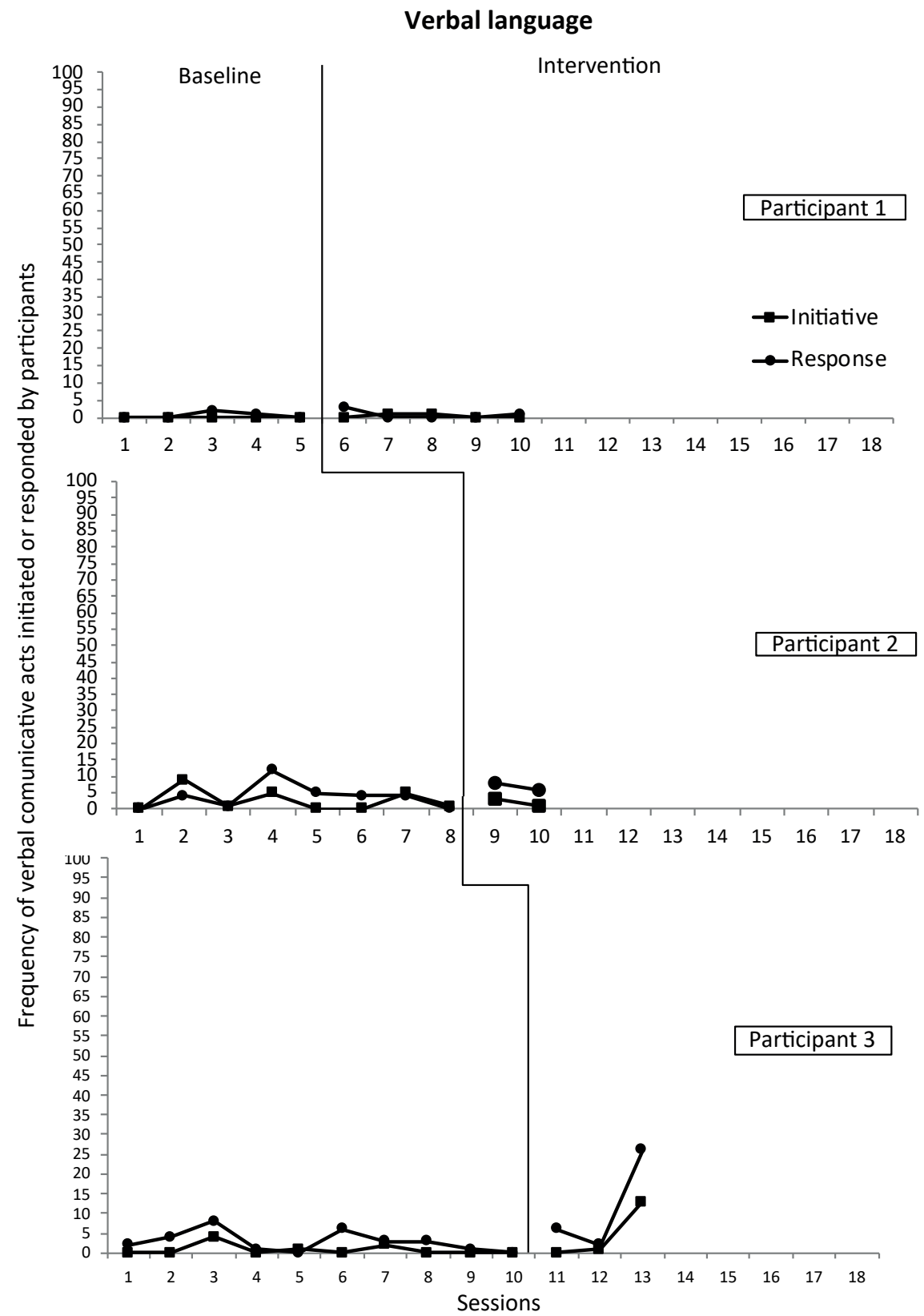

Figure 3.1. Frequency of verbal and nonverbal communicative acts initiated and responded by ASD participants in the Specialized Educational Assistance (SEA) and classroom contexts. 


\section{Specialized Educational Assistance (SEA):}

Non-verbal language (initiative): Visual analysis indicates an immediate increase in nonverbal initiatives of participant 1 in the SEA from the first data point of the intervention in a growing trend $\left(\bar{X}_{A}=3.2 ; 2<>4 ; \bar{X}_{B}=18 ; 14<>25\right)$. Scores of nonverbal initiatives of participant 2 were higher in the intervention phase, with an increasing trend $\left(\bar{X}_{A}=0.75 ; 1<>2 ; \bar{X}_{B}=4 ; 2<>8\right)$. For participant 3 , there was a low frequency of non-verbal initiatives in the baseline $(\bar{X}=1.75 ; 0<>11)$. Participant 3 demonstrated 11 communicative acts only in session 8 . During the intervention, the data varied in a growing trend $(\bar{X}=3.8 ; 1<>8)$

Non-verbal language (response): The frequency of non-verbal responses at intervention was higher than the baseline for participant $1\left(\bar{X}_{A}=11,8 ; 11<>27\right.$; $\left.\bar{X}_{B}=23 ; 11<>37\right)$, who showed a decreasing trend and for participant $2\left(\bar{X}_{A}=9.75\right.$; $\left.3<>36 ; \bar{X}_{B}=18.8 ; 14<>20\right)$. For participant 3 , there was a higher data variability at the baseline $(\bar{X}=59.75 ; 34<>83)$, while the frequency of nonverbal responses followed a decreasing trend in intervention phase $(\bar{X}=44.6 ; 37<>57)$.

Verbal Language (initiative): The average frequency of verbal initiatives issued in the SEA was higher at the intervention phase than in the baseline with a growing trend for participant $1\left(\bar{X}_{A}=15,6 ; 13<>18 ; \bar{X}_{B}=23,6 ; 16<>41\right)$ and for participant 3 $\left(\bar{X}_{A}=1 ; 0<>4 ; \bar{X}_{B}=6.2 ; 1<>15\right)$. Participant 2 obtained averages of similar verbal initiatives in both phases $\left(\bar{X}_{A}=13,6 ; 8<>24 ; \bar{X}_{B}=13.8 ; 7<>17\right)$, demonstrating no significant increase after the introduction of the intervention phase.

Verbal Language (response): The frequency of verbal responses issued by participant 1 in SEA was higher at the baseline $(\bar{X}=56.6 ; 43<>73)$ than in $B(\bar{X}=55.2$; $36<>99)$, with an increasing trend. The large variability and decreasing trend in $B$ indicates a gradual reduction of acts answered by participant 1 in this phase. The same tendency of the data occurred with participants 2 and 3, with averages of $B$ $(\bar{X}=41.4 ; 28<>57$ e $\bar{X}=29.2 ; 27<>40)$ lower than the baseline $(\bar{X}=50.7 ; 40<>$ 83 e $\bar{X}=37 ; 13<>81$ ).

\subsection{Quality of communicative acts in the SEA}

Between the phases of the study, participants 1 and 3 experienced changes in the quality of verbal initiatives during the SEA. Participant 1 increased his verbal initiatives $\left(\bar{X}_{A}=15.2 ; \bar{X}_{B}=25.9\right)$ e $3\left(\bar{X}_{A}=1.1 ; \bar{X}_{B}=6.2\right)$ according to that context, that is, the communicative acts were related to the subject or theme addressed in the class. 
There was also an increase in eye contact for participants $1\left(\bar{X}_{A}=0.6 ; \bar{X}_{B}=5.4\right)$ and $3\left(\bar{X}_{A}=0.1 ; \bar{X}_{B}=1.8\right)$. One of the absent aspects at the baseline was the use of facial expression by participant 1 , which was evident during the intervention $\left(\bar{X}_{B}=1.4\right)$, with progress in this ability between phases; this also occurred for participant $3\left(\bar{X}_{A}=0.1 ; \bar{X}_{B}=1.4\right)$. Participant 2 did not present changes between the phases in the quality of verbal communicative acts with initiative. Concerning the quality of the verbal acts issued in response situations, the three participants showed progress in eye contact (participant $1, \bar{X}_{A}=1.4 ; \bar{X}_{B}=10.4$; participant $2, \bar{X}_{A}=0.1$; $\bar{X}_{B}=1.8$; participant 3, $\left.\bar{X}_{A}=2.6 ; \bar{X}_{B}=11.4\right)$. Only participant 1 had differences regarding the use of a facial expression in his verbal responses $\left(\bar{X}_{A}=0.8 ; \bar{X}_{B}=2\right)$ during communication.

There was an increase in non-verbal initiatives according to context only for participant $1\left(\bar{X}_{A}=2.8 ; \bar{X}_{B}=16.8\right)$. Progress regarding the use of eye contact $\left(\bar{X}_{A}=\right.$ $\left.0.2 ; \bar{X}_{B}=3.6\right)$, facial expression $\left(\bar{X}_{A}=0.4\right.$ e $\left.\bar{X}_{B}=1,6\right)$, and touch $\left(\bar{X}_{A}=0,8\right.$ e $\left.\bar{X}_{B}=1,4\right)$ were evident only for this participant. Regarding the quality of non-verbal responses, there were changes between the phases for the three participants in the use of eye contact, as follows: participant $1\left(\bar{X}_{A}=0.2 ; \bar{X}_{B}=3.6\right)$; participant $2\left(\bar{X}_{A}=\right.$ $\left.0.3 ; \bar{X}_{B}=0.6\right)$; participant $3\left(\bar{X}_{A}=2.7 ; \bar{X}_{B}=5.8\right)$. Increased non-verbal responses in SEA within the context were observed for participants $1\left(\bar{X}_{A}=2.8 ; \bar{X}_{B}=16.8\right)$ and 2 $\left(\bar{X}_{A}=8.8 ; \bar{X}_{B}=17.6\right)$.

\section{Classroom}

Non-verbal language (initiative): The data corresponding to non-verbal initiatives in the classroom did not present expressive differences between the baseline and $B$ phases for all participants, with values close to zero both at the baseline $(\bar{X}=0 ; 0.75 ; 0.3$ for participants $1,2,3$, respectively) and in the intervention phase $(\bar{X}=0.6 ; 0 ; 1.3$ for participants $1,2,3$, respectively).

Nonverbal language (response): Non-verbal responses in the classroom also did not present significant differences between the phases for participants 1 and 3 , with values close to zero both at the baseline $(\bar{X}=0.2$ and 3.5 , respectively) and $B$ $(\bar{X}=0.6$ and 4 , respectively) phases. Only participant 2 had a sharp increase in verbal responses in the classroom with an increasing tendency $\left(\bar{X}_{A}=0.1\right.$ and $\bar{X}_{B}=$ 4.5); however, there were only two sessions of data sampling for this participant. 
Verbal language (initiative): The results obtained for the average frequency of verbal initiatives in the classroom were not very expressive, with a decreasing tendency in $\mathrm{B}$ for participant $1\left(\bar{X}_{A}=0\right.$ and $\left.X_{B}=0.4\right)$ and participant $2\left(\bar{X}_{A}=2.6\right.$ and $\bar{X}_{B}$ = 1.5). Participant 3 had an average $B(\bar{X}=4.6)$ higher than the baseline $(\bar{X}=0.7)$, due to the significant increase in verbal initiatives in the last session of data sampling.

Verbal language (response): The participants' verbal responses were infrequent, with a decreasing tendency for participant $1\left(\bar{X}_{A}=0.6 ; \bar{X}_{B}=0.8\right)$. On the other hand, participants $2\left(\bar{X}_{A}=3.75 ; \bar{X}_{B}=7\right)$ and $3\left(\bar{X}_{A}=2.8 ; \bar{X}_{B}=3.4\right)$ showed an increase in verbal responses in the classroom based on only two sessions of data sampling.

Qualities of communicative acts in the classroom: No changes were observed in the quality of the communicative acts (verbal and non-verbal language) of the participants in the common classroom. Besides the visual analysis of the data, the analysis of the statistical significance of the differences found was performed ( $p \leq$ 0.05). Table 3.1 summarizes the percentage of change between the phases of the studied variables, based on the calculation of the Tau- $U$ with their respective $p$-values and confidence intervals.

The results from the calculation of Tau- $U$ effect size referring to the frequencies of non-verbal initiatives issued by the three participants in the SEA showed considerable increases between the phases, with statistical significance $(p<0.05)$ for all of them. The size of the changes found for participant 1 was $100 \%$ (Tau-U $=1$ ); i.e., there was a substantial effect. For participants 2 and 3, there were improvements of $80 \%$ and $60 \%$ between the phases, respectively. The omnibus effect size of the study (Tau-U $=0.8, p<0.05$ ) indicates a substantial effect of $B$ on the increase of participants' nonverbal communication initiatives.

Regarding the non-verbal responses issued by the three participants in the SEA, there was a change between the phases, with $60 \%$ improvement for participant 1 and $50 \%$ for participant 2, characterizing a moderate to substantial effect. For participant 3 , the negative value of Tau- $\mathrm{U}(-0.6)$ indicates a reduction of $60 \%$ of the non-verbal acts answered by this participant during the intervention. The data presented for the three participants are not statistically significant $(p>0.05)$, although the social relevance of the findings should not be dismissed concerning the form of communication established by them during the intervention. 
Table 3.1. Individual and overall Tau- $U$ effect sizes for the frequency of verbal and nonverbal communicative acts initiated or responded by participants.

\begin{tabular}{|c|c|c|c|c|c|c|c|}
\hline \multicolumn{8}{|c|}{ SEA } \\
\hline \multicolumn{5}{|c|}{ Nonverbal Language } & \multicolumn{3}{|c|}{ Verbal Language } \\
\hline \multirow{6}{*}{ Initiative } & Participant & Tau-U & $\mathrm{p}$-value & $90 \% \mathrm{Cl}$ & Tau-U & $\mathrm{p}$-value & $90 \% \mathrm{Cl}$ \\
\hline & 1 & 1.0 & 0.009 & $0.370<>1$ & 0.7 & 0.04 & $0.130<>1$ \\
\hline & 2 & 0.8 & 0.01 & $0.288<>1$ & 0.07 & 0.8 & $-0.487<$ \\
\hline & & & & & & & $>0.637$ \\
\hline & 3 & 0.6 & 0.04 & $0.113<>1$ & 0.8 & 0.01 & $0.238<>1$ \\
\hline & Omnibus & 0.8 & 0.000 & $0.494<>1$ & 0.5 & 0.009 & $\begin{array}{c}0.193< \\
>0.865\end{array}$ \\
\hline \multirow{5}{*}{ Response } & 1 & 0.6 & 0.07 & $0.050<$ & -0.5 & 0.1 & $-1.000<$ \\
\hline & & & & $>1$ & & & $>0.070$ \\
\hline & 2 & 0.5 & 0.10 & $\begin{array}{c}-0.012< \\
>1\end{array}$ & -0.2 & 0.4 & $\begin{array}{c}-0.837< \\
>0.287\end{array}$ \\
\hline & 3 & -0.6 & 0.07 & $\begin{array}{c}-1< \\
>-0.038\end{array}$ & -0.4 & 0.2 & $\begin{array}{c}-0.987< \\
>0.137\end{array}$ \\
\hline & Omnibus & 0.1 & 0.39 & $\begin{array}{c}-0.160< \\
>0.512\end{array}$ & -0.4 & 0.04 & $\begin{array}{l}-0.746< \\
>-0.074\end{array}$ \\
\hline \multicolumn{8}{|c|}{ Classroom } \\
\hline \multicolumn{5}{|c|}{ Nonverbal Language } & \multicolumn{3}{|c|}{ Verbal Language } \\
\hline \multirow{6}{*}{ Initiative } & Participant & Tau-U & $\mathrm{p}$-value & $90 \% \mathrm{Cl}$ & Tau-U & p-value & $90 \% \mathrm{Cl}$ \\
\hline & 1 & 0.4 & 0.2 & $\begin{array}{c}-0.230< \\
>0.670\end{array}$ & 0.4 & 0.2 & $\begin{array}{c}-0.230< \\
>1\end{array}$ \\
\hline & 2 & -0.5 & 0.2 & $-1<$ & 0.1 & 0.7 & $-0.662<$ \\
\hline & & & & $>0.287$ & & & $>0.912$ \\
\hline & 3 & 0.5 & 0.2 & $\begin{array}{c}-0.215< \\
>1\end{array}$ & 0.4 & 0.3 & $\begin{array}{c}-0.249< \\
>1\end{array}$ \\
\hline & Omnibus & 0.21 & 0.370 & $\begin{array}{c}-0.179< \\
>0.605\end{array}$ & 0.33 & 0.1637 & $\begin{array}{c}-0.060< \\
>0.724\end{array}$ \\
\hline \multirow{4}{*}{ Response } & 1 & 0.04 & 0.9 & $\begin{array}{c}-0.590< \\
>0.670\end{array}$ & 0.04 & 0.9 & $\begin{array}{c}-0.590< \\
>0.670\end{array}$ \\
\hline & 2 & 0.93 & 0.05 & $\begin{array}{c}0.088< \\
>1\end{array}$ & 0.75 & 0.11 & $\begin{array}{c}-0.037< \\
>1\end{array}$ \\
\hline & 3 & -0.1 & 0.79 & $\begin{array}{c}-0.749< \\
>0.549\end{array}$ & 0.53 & 0.17 & $\begin{array}{c}-0.115< \\
>1\end{array}$ \\
\hline & Omnibus & 0.21 & 0.3753 & $\begin{array}{l}-0.181< \\
>0.603\end{array}$ & 0.33 & 0.1637 & $\begin{array}{c}-0.060< \\
>0.788\end{array}$ \\
\hline
\end{tabular}


The calculation of the Tau- $U$ effect size shows that the size of the changes found between the phases on verbal initiatives of participant 1 in SEA was $70 \%$ and, for participant 3,80\%; these results characterize a moderate to substantial effect (Parker \& Vannest, 2012) with statistical significance for both ( $p<0.05)$. For participant 2 , there was a small effect of $7 \%(\mathrm{Tau}-U=0.07)$ between the phases with no statistical significance $(p=0.8)$. Although there was no statistically significant change for participant 3 , the omnibus effect size (Tau-U $=0.5$ ) indicates a statistically significant difference ( $p<0.05$ ) of 50\% overall improvement in the participant's verbal initiatives.

Regarding verbal responses in SEA, a reduction in the scores for all the participants during the intervention was evidenced, as shown by the negative values of Tau-U. This reduction indicates that there was no progress from one phase to another concerning this variable in the study.

The Tau- $U$ effect size calculation showed that the size of the changes found between the phases about verbal initiatives of participants 1 and 3 in the classroom was $4 \%($ Tau $-U=0.4)$, considered a moderate effect. For participant 2 , there was a small effect of $1 \%(\mathrm{Tau}-U=0.1)$; the results for all participants were not statistically significant $(p>0.05)$.

There was no improvement in the verbal responses issued by participant 1 in the classroom (Tau-U = 0.0). For participants 2 and 3, there were improvements of $70 \%$ and $50 \%$, respectively; however, there was no statistical significance for any participant ( $p>0.05$; Parker \& Vannest, 2012). The results of the calculation of Tau-U effect size for non-verbal classroom initiatives showed that the observed effects were equal to or less than $50 \%$ and did not show statistical significance for any of the participants ( $p>0.05$ ). There was a reduction of communicative acts by participant 2 between the phases, as indicated by the negative Tau-U value (Parker $\&$ Vannest, 2012). Only participant 2 achieved a statistically significant improvement ( $p<0.05$ ) of $90 \%$ in non-verbal responses in the classroom. However, there were only two intervention sessions for this participant, and the rate of nonverbal responses increased as a result of interactions with colleagues when greeting each other.

At the end of the intervention, responses to the social validity questionnaire indicated that the SEA teacher considered the intervention easy to apply, and with the possibility of implementation in the context of the SEA. The teacher noticed that the intervention increased the interaction and the communication of the 
students, promoting active participation. The teacher also noted that the planned and structured activities favored students' understanding, raising new perceptions about attendance. Finally, the teacher expressed an interest in adapting the activities of the SEA plan to the proposals related to SRL and stated that this type of intervention is recommendable to other SEA teachers.

\section{Discussion}

According to the Brazilian Policy on Special Education from an Inclusive Education's perspective (Brasil, 2008), the SEA aims to complement or supplement student education for autonomy in the social context. Therefore, we sought to verify the impact of the intervention on the frequency and quality of communicative acts of children with ASD in the context of the SEA, as well as in the common classroom. It is important to emphasize that the logic sequence used in the intervention was common for the three participants, but also considered the individual needs of the students, such as interests (e.g., Peppa Pig (cartoon character) 's theme for participant 1) and learning pace (e.g., used as a "time management" resource for participant 2, which increased organization allowing the completion of tasks).

There was progress with statistical relevance in the frequency of verbal initiatives in SEA for participants 1 and 3, as well as in the form of communication established to make choices and decisions to accomplish tasks. It was observed that the participants modified their communication when challenged to perform tasks; participants planned, executed, and evaluated personal actions. Participant 1 demonstrated initiatives to make decisions regarding doubts in the ability to perform tasks related to the activity, as well as showed a desire to share subjects of interest with the teacher. On the other hand, participant 3 demonstrated initiative in the strategy of asking for help, making choices based on the questions involved in the intervention, and showing doubts primarily about the writing of words. The verbal initiatives of participant 2 were characterized by making requests during tasks and acknowledging the reasons why objectives were not attained when reviewing personal records during the construction of portfolios. Although statistically significant improvement was not found, these skills are relevant to the organization of thinking and understanding the social function of language usually impaired in ASD individuals, since the process of self-regulation enables the individual to manage behaviors and thoughts when challenged to list goals and plan, 
perform, and evaluate tasks. Thus, behaviors were mobilized by students by having to seek strategies to deal with doubts or difficulties, such as asking for help, which involves the making of statements and efforts for this purpose (Zimermman, 2013). This strategy challenges the student to deal with challenges and difficulties, mobilizing internal processes that allow the student to perceive the need to seek help to solve problems in specific situations (Serafin \& Boruchovitch, 2010).

The mobilization of these internal processes can be favorable to the development of communication, once students begin to communicate with each other. Joint attention characterizes this action, as focus on multiple references is required (Tomasello, 2003); in this case, the use of the resources for acquiring assistance and the interaction with the teacher in the presence of doubts or difficulties. Thus, it is fundamental to provide challenging situations for the student, offer possibilities for the student to take initiatives, form strategies, and attain resources that can help with problem-solving.

We observed that verbal initiatives might suffer motivational influences due to daily events (such as debilitated health and change of routines of participants 2 and 3 , respectively), requiring more orientation and guidance from the teacher. The presence of passive behaviors is contrary to the concept of essential human agency in the process of self-regulation, in which the individual poses as an active subject that manages personal thoughts and behaviors in accordance with the goal (Emílio, 2017).

The quality of verbal initiatives demonstrated by the three participants was consistent in the context of the classroom. The average between the phases in this topic varied according to the number of acts displayed by the participants. Participants 1 and 3 demonstrated an increased frequency of verbal initiatives with eye contact in SEA. Participant 1 also showed improvement regarding facial expression, while participant 2 did not present any advances regarding this behavior between the phases. The increase of these abilities allows the synchronization of attention between adult and child, favoring the interaction and the development of intentional actions. By perceiving the other as an intentional agent, the individual also begins to mobilize behaviors to achieve objectives, using them as a communicative function (Tomasello, 2003).

As a tool for declaring or seeking help for joint attention, communication requires alternating roles (Bosa, 2002). Therefore, the skills to initiate and respond 
to a communicative interaction are essential. However, difficulties in communicating and interacting restrict the voluntary initiatives of ASD individuals, who often only respond when requested. While responding to others occurs according to social stimuli, initiatives require more complex skills related to executive functions, such as planning and monitoring to reach goals (Zanon, Backes, \& Bosa, 2015).

Therefore, the regression regarding the frequency of acts verbally answered by the participants is considered positive. As the verbal initiatives increased, there was an increase in the verbal communicative repertoire by initiative, a commonly harmed characteristic and a precursor of social isolation in individuals with ASD. Another positive aspect of the interventions was that the participants modified their dialogue form, reducing the frequency of laconic responses of the type "yes," "no," "ok," to demonstrate actions to be taken during a problematic situation. Verbal responses of the participant in the intervention expanded into more complex statements to allow the development of decision-making, the demonstration of needs, the formulation of goals, and the ability to verbalize confidence in achieving goals. This was evident when participant 2 verbalized that he was unable to think, thus recognizing that the support of the teacher was necessary.

Additionally, there was an increase in the frequency of verbal acts answered with eye contact for the three participants. However, only participant 1 also demonstrated progress in facial expression. We, therefore, note that the verbal responses of the three participants began to show an evolution in behavior related to shared attention, since individuals can perceive the behavioral reactions of others by sharing experiences and understanding the symbolic representations that are part of the communication process (Bosa, 2002).

Parallel to the increase in initiatives and decrease of verbal responses, there was a statistically significant difference in the frequency of nonverbal initiatives for all participants; participant 1 showed immediate changes, whereas participants 2 and 3 showed gradual changes. At the baseline, nonverbal manifestations of the participants were restricted to gestures to demonstrate wishes (e.g., pointing to the toy box) (participant 1), showing the teacher the steps of a task by pointing to the next step (participant 1), and asking for assistance (e.g., showing dirty hands while using the pencil sharpener; participant 2). During the intervention, participants broadened non-verbal initiatives, demonstrating attempts to share interests. This was evident when participant 1 represented an action, showing the 
teacher that the character in a story was afraid. Participant 2 began to use the pointing gesture along with verbal language, sharing ideas during the evaluation of personal records, and showing conclusions. Finally, participant 3 used non-verbal communication to show the words that should be rewritten at the time of portfolio construction and to indicate that assistance was required by pointing the finger at doubts or difficulties on the task.

The changes that occurred regarding the form of communication using nonverbal acts is positive for the development of social communication, since the use of gestures favors the interaction and the amplification of symbolic representations (Tomasello, 2003). In this established interaction, the individual can broaden their repertoire of communication, mobilizing behaviors to reach objectives, thus allowing their perception as an intentional agent (Tomasello, 2003). Several initiatives presented by participants 1 and 2 occurred from problematic situations, which challenged the participants to set objectives. The use of visual resources at the time positively favored the participation of the students on the different topics addressed. In the same way, participants 2 and 3 demonstrated initiatives in the construction of portfolios by showing words that should be arranged and identifying tasks that were still incomplete.

Cunha (2009) stated that the use of visual aids favors the understanding of children with ASD, as visual images remain in memory for a longer time, unlike verbal information. Communication can be explored in the school context in a variety of ways, and the teacher can use diverse resources, including visual ones, so that ASD children can understand the request of a task and participate effectively in its resolution, with opportunities to express ideas in different ways.

We verified that the nonverbal initiatives of the three participants took place within the context, that is, these acts demonstrated coherence with the subject, and the theme applied. Between the phases of the study, the frequency regarding the quality of communicative acts for participants 1 and 3 increased, while for participant 2 it remained unchanged. Participants 1 and 3 demonstrated an increase in the frequency of these acts with facial expression, and participant 1 also demonstrated advances with eye contact and touch. In line with previous studies (Bosa, 2002; Tomasello, 2003), we suggest that this progress is related to the development of shared attention that positively affects the process of interaction and communication. 
Although differences in the frequencies of nonverbal responses in the SEA were not statistically significant, they increased for participants 1 and 2. However, there was a gradual reduction of the results, maintaining a downward trend. The highest index of nonverbal responses occurred from the use of visual resources, often accompanied by verbalizations along with the gesture of pointing to demonstrate an understanding of images. This indicates that the communicative performance of students with ASD is affected by the nature of the proposed tasks and resources used, as reported in other interventional studies with ASD children in inclusive school contexts (Ramos et al., in press). Likewise, participant 3 began to use different ways of expressing non-verbal acts in the intervention because the questions by the teacher were directed to the possibilities of the participant to make choices and decisions, thus reducing the index of gestures with the head to express agreement or disagreement, as found at the baseline. There was progress in the form of non-verbal communication established by the participants because the actions performed correlated with the intentions of the participants to make statements and requests for assistance, as well as to share or demonstrate ideas and thoughts according to objectives to be achieved in the tasks. The quality of these non-verbal acts also improved among the participants, albeit in a different way. The higher frequency of non-verbal responses within the context is especially crucial for participant 1 , who has echolalia and, thus repeats questions and greetings from others. Progress in the averages of facial expression (participants 1 and 3) and eye contact and touch (participant 1) also suggest that the intervention based on SRL has the potential to favor the development of communication and language precursor skills. Also, the expansion of the symbolic repertoire is evident with the increase of the nonverbal initiatives, as the answers gradually reduced for the three participants. Some sessions demonstrated communication involving alternating roles, which presupposes a relationship of reciprocity and interaction in the communication established with the teacher.

In conclusion, the general effect of the intervention measured by the omnibus effect size in SEA showed an increase in verbal initiatives and a reduction for verbal responses, both with statistical significance during the intervention. Considering nonverbal language in the SEA, the omnibus effect size indicated a very large and statistically significant for the nonverbal initiatives of the participants, while for nonverbal responses there was a small without statistical significance. 
This demonstrates that the intervention effectively contributed to the verbal and nonverbal initiatives of the participants, which are considered fundamental to the processes of communication, interaction, and language development. Participants shifted from responding to stimuli only to mobilizing behaviors to communicate desires, wishes, and interests. However, this was not observed in the context of the common classroom since the omnibus effect size for the acts of verbal communication initiated and answered by the participants had a moderate effect of $33 \%$, although with no statistical significance. The responses using nonverbal language also had a small general effect of $21 \%$, both about initiatives and responses. These differences did not present statistical significance, indicating a considerably lower impact of the intervention in verbal and nonverbal communicative acts in the common classroom compared to SEA. The progress in the communication of the participants occurred in the SEA, possibly because this was the context where the intervention was implemented, based on the SRL process. The non-generalization of gains in SEA for the common classroom can be explained by the recurrent difficulty of individuals with ASD to transfer skills acquired in one context to another. When performing tasks, the students went through the phases of the SRL when planning, executing and evaluating personal productions; students had the opportunity to be autonomous and active subjects in individual learning in the context of the SEA. The work developed in the SEA is aimed at the development of the abilities and potentialities of ASD students, aiming to increase autonomy and participation in the school context. Therefore, it is essential to verify possible impacts on the communication of the participants in the context of the common classroom. However, the results of this study suggest that the intervention based on SRL only during SEA will contribute little to the communication of ASD students if there is no complementary work between SEA and common teachers, as advocated by inclusive policies (Brazil, 2008), in addition to the teacher involvement in conducting intervention in the classroom. The non-participation of the common classroom teacher in the intervention was one of the main limitations of this study and shall be considered in future investigations. Also, other limitations of this study should be considered in the analysis of the results, such as health problems of the participants and absences in the common classroom, which generated limited data in the intervention phase in this context. The number of participants met the minimum criteria to obtain experimental control and to establish a functional 
relationship in single case studies. However, it is important that further research is carried out to verify the contributions of SRL to the communication of ASD students, to be used as an external validity criterion to establish evidence-based practices. Considering the importance of the SEA for inclusive education and the SRL contributions in the communication of the participants in this study, the positive evaluation of the social validity of the intervention of the SEA teacher is favorable for its implementation by current SEA teachers and the education of other SEA teachers. The SEA teacher appropriated and used SRL strategies in her pedagogical practice, following the development of the communication of her students. It is possible that other children can also benefit from the contributions of this work from the pedagogical practice developed by both the SEA teacher and the common classroom teacher.

Finally, we suggest that future studies include monitoring teacher's behavior, as it seems to moderate students' communication skills. New studies also should focus on SRL in the context of the common classroom and invest in the education of teachers regarding the contributions of SRL to students with autism.

\section{References}

Alberto, P. A., \& Troutman, A. C. (2009). Applied behavior analysis for teachers (8th ed.). Upper Saddle River, NJ: Merrill.

American Psychiatric Association (2014). Manual diagnóstico e estatístico de transtornos mentais. ( $5^{\mathrm{a}}$ ed.). Porto Alegre: Artmed.

Backes, B., Zanon, R. B., \& Bosa, C. A. (2013). A relação entre regressão da linguagem e desenvolvimento sociocomunicativo de crianças com transtorno do espectro do autismo. CoDAS, 25(3), 268-273. doi:10.1590/S2317-17822013000300013

Bosa, C. A. (2001). As relações entre Autismo, Comportamento Social e Função Executiva. Psicologia: Reflexão e Crítica, 14(2), 281-287. doi:10.1590/So10279722001000200004

Bosa, C. (2002). Atenção compartilhada e identificação precoce do autismo. Psicologia Reflexão e Crítica, 15(1), 77-88. doi:10.1590/S0102-79722002000100010

Bosa, C. (2006). Autismo: intervenções psicoeducacionais. Revista Brasileira de Psiquiatria, 28(1), S47-S53. doi:10.1590/S1516-44462006000500007 
Brasil (2008). Política Nacional de Educação Especial na Perspectiva da Educação Inclusiva. Inclusão, 4(1), 7-17.

Cunha, E. (2009). Autismo e Inclusão. Psicopedagogia e práticas educativas na escola e na família. Rio de Janeiro: Wak. Ed.

Czermainski, F. (2012). A avaliação neuropsicológica das funções executivas no transtorno do espectro do autismo. Dissertação (Mestrado em Psicologia), Universidade Federal do Rio Grande do Sul, Brasil.

Czermainski, F., Bosa, C., \& Salles, J. (2013). Funções executivas em crianças e adolescentes com Transtorno do Espectro do Autismo: Uma revisão. Psico, 44(4), 518-525.

Czermainski, F. R., Riesgo, R. S., Guimarães, L. S. P., Salles, J. F., \& Bosa, C. A. (2014). Executive functions in children and adolescents with Autism Spectrum Disorder. Paidéia (Ribeirão Preto), 24(57), 85-94. doi:10.1590/1982-43272457201411

Dias, N., \& Seabra, A. (2013). Programa de Intervenção em Autorregulação e funções executivas. São Paulo: Memnon.

Emílio, E. (2017). Autorregulação, autoeficácia, abordagens à aprendizagem e a escrita de universitários. 250f. Tese (Doutorado em Educação, Unicamp).

Happé, F., \& Frith, U. (1996). The neuropsychology of autism. Brain, 119, 1377-1400.

Horner, R. H., Carr, E. G., Halle, J., McGee, G., Odom, S., \& Wolery, M. (2005). The use of single-subject research to identify evidence-based practice in special education. Exceptional Children, 71(2), 165-179.

Nunes, L. R., \& Walter, C. C. (2014). Pesquisa Experimental em educação especial. In Nunes, L. (Org.), Novas trilhas no modo de fazer pesquisa em Educação Especial (pp. 27-51). Marília: ABPEE/Marquezine Manzini.

Porciuncula, R. A. (2016). Investigação precoce do Transtorno do Espectro Autista: Sinais que alertam para a intervenção. In N. T. Rotta, C. A. Bridi Filho, F.R. S. Bridi (Org.), Neurologia e aprendizagem. (pp. 29-54).). Porto Alegre: Artmed.

Parker, R., \& Vannest, K. J. (2012). Bottom-up analysis of single-case research designs. Journal of Behavioral Education, 21(3), 254-265.doi:10.1007/s10864-012-9153-1

Ramos, F. S., Bittencourt, D. D., Camargo, S. P. H., \& Schmidt, C. (in press). Intervenção mediada por pares no engajamento acadêmico de alunos com autismo. Educação Temática Digital. doi:10.20396/etd.voio.8646231 
Ropoli, E. A., Mantoan, M. T. E., Santos, M. T. C. T., \& Machado, R. (2010). A escola comum Inclusiva. Brasília, DF: SEE/UFC.

Serafin, T., \& Boruchovitch, E. (2010). A estratégia de pedir ajuda em estudante do ensino fundamental. Psicologia: Ciência e Profissão, 30(2), 404-417.

Tomasello, M. (2003). Origens culturais da aquisição do conhecimento humano. São Paulo: Martins Fontes.

Zanon, R. B., Backes, C. A., \& Bosa, C. (2015). Diferenças conceituais entre resposta e iniciativa de atenção compartilhada. Psicologia: Teoria e Prática, 17(2), 78-90.

Zimmerman, B. J. (2013). From cognitive modeling to self-regulation: A social cognitive career path. Educational Psychologist, 48(3), 135-147. doi:10.1080/00461520 .2013 .794676

\section{Authors notes}

Andréia T. Leão, Departament of Educational Foundations, Federal University of Pelotas (UFPel); Siglia P. H. Camargo, Departament of Educational Foundations, Federal University of Pelotas (UFPel); Lourdes Maria B. Frison, Departament of Educational Foundations, Federal University of Pelotas (UFPel).

Project funded by CNPq-Universal (Process 42831 8/2016-9).

Correspondence concerning this article should be addressed to Síglia Pimentel Höher Camargo, Universidade Federal de Pelotas, Faculdade de Educação, Rua Alberto Rosa, 154, Porto, Pelotas, RS, Brazil. CEP 96010-770.

E-mail: sigliahoher@yahoo.com.br 